Volume I Tahun 2021

November 2021
E-ISSN: 2808-5361

http://e-journal.fkmumj.ac.id/
Proceeding The First

Muhammadiyah Internasional-

Public Health and Medicine

Conference

\title{
Immunization Visit Delay in Children Aged 0-24 Months During The Covid-19 Pandemic in Greater Jakarta
}

\author{
${ }^{1}$ Istianah Surury, ${ }^{2}$ Siti Riptifah Tri Handari \\ Faculty of Public Health, Muhammadiyah University of Jakarta \\ K.H. Ahmad Dahlan St, Cireundeu, Ciputat, South Jakarta, 15419 \\ E-mail: istianah.surury@umj.ac.id
}

\begin{abstract}
The COVID-19 pandemic since the beginning of 2020 has had a significant impact on other essential health services. One of them is the immunization service. Jakarta, Depok, Tangerang, and Bekasi, or Greater Jakarta is the epicenter of the spread of COVID-19 in Indonesia. This study aimed to find the distribution of immunization delay in women with children aged 0-24 months and its reasons in Greater Jakarta. This study used an observational method with a cross-sectional study design. The research process was carried out for six months, from June to November 2020, and 274 samples were collected through online google forms. The study found the proportion of mothers who delayed their children's immunization was 48,9\%. The most common reasons are fear of being infected with COVID-19, health facilities not providing immunizations for children, limited vaccine availability, and declining family income during the pandemic. The government should increase the promotion of primary immunization to the community and ensure the availability, safety, and implementation of health protocols in health care facilities.
\end{abstract}

Keywords: Children aged 0-24 months, COVID-19 pandemic, Greater Jakarta, Immunization visit delay 
E-ISSN: 2808-5361 http://e-journal.fkmumj.ac.id/
Proceeding The First Muhammadiyah InternasionalPublic Health and Medicine Conference

\section{INTRODUCTION}

Coronaviruses are a large family of viruses that cause disease in humans and animals. It usually causes respiratory tract infections in humans, ranging from the common cold to severe illnesses such as Middle East Respiratory Syndrome (MERS) and Severe Acute Respiratory Syndrome (SARS). A new type of coronavirus found in humans since an outbreak event appeared in Wuhan, China, in December 2019, was later named Severe Acute Respiratory Syndrome Coronavirus 2 (SARS-COV2) and caused Coronavirus Disease-2019 (COVID-19). ${ }^{1}$

The first case of COVID-19 was discovered in Indonesia on March 2, 2020. Two Indonesian citizens (WNI) who live in Depok have tested positive for the SARS Cov-2 virus. The two Covid-19 sufferers have a history of interacting with Japanese citizens who have suffered from the disease. The number of COVID-19 cases continues to grow every day, both in the world and in Indonesia. As of June 10, 2020, more than 7 million people were infected with COVID-19 globally, and more than 30 thousand people were infected with COVID-19 in Indonesia. $^{2}$

The COVID-19 pandemic since the beginning of 2020 has had a significant impact on other essential health services. One of them is the immunization service. Based on a study conducted in the United States in March-April 2020, there was a sharp decline in routine immunization of children., Based on the results of a survey conducted by the Ministry of Health with UNICEF in April 2020, it was found that 83.9\% of immunization services in Indonesia were affected by the COVID-19 pandemic. $^{5}$ This has happened almost evenly in all provinces in Indonesia. Implementation of complete primary immunization in Papua Province is still low amid the Covid-19 pandemic. According to reports from 28 districts and two cities in Papua, immunization coverage has only reached 41.8 percent of the target of 68,370 children. $^{6}$

The Indonesian Pediatrician Association (IDAI) feared that decreasing immunization visit coverage will create a new problem, namely a double outbreak. The dual epidemic is recent attacks due to diseases that should be prevented by immunization (PD3I) during the COVID-19 pandemic. ${ }^{7}$ This is a real threat to Indonesia, especially if immunization services are not immediately addressed. Greater Jakarta itself is the epicenter of the spread of COVID-19 in Indonesia, facing the same problem. Concerning the background described, it is necessary to conduct a study that aims to identify the determinants that affect childhood immunization visits, especially primary immunization for infants aged 0-12 months in Greater Jakarta.

\section{METHODS}

This study used an observational method with a cross-sectional study design. The research process was carried out for six months, from June to November 2020. The general 
population in this study were all couples of childbearing ages in Greater Jakarta (Jakarta, Depok, Tangerang, and Bekasi). At the same time, the target population is all couples of childbearing age in Greater Jakarta who have children aged 0-24 months. The study population in this study were all couples of childbearing ages in Greater Jakarta who have children aged 024 at the time of the survey.

The inclusion criteria in this study were couples of childbearing ages in Greater Jakarta who have children aged 0-24 since January 2020, intend or have routinely immunized their children since before the COVID-19 pandemic, and became respondents. The exclusion criteria were respondents who filled out the questionnaire incompletely.

The formula calculates the minimum number of samples in this study to estimate the proportion of one population with an error tolerance of $5 \%{ }^{8}$ The minimum sample size is 267 respondents. The sampling technique was using purposive sampling following the inclusion and exclusion criteria of the study. Data collection is done online using Google Forms. A total of 302 samples were collected, and 274 were eligible. Data were analyzed by univariate test to see the proportion of each variable category.

\section{RESULTS AND DISCUSSIONS}

There are 274 samples collected in this study. It was found that $48.9 \%$ of mothers had delayed immunization visits for their children. The main reasons for the delay were the fear of being infected with COVID-19, health facilities not providing immunization services, decreasing family income, and the shortage of vaccines for children.

Table 1. Distribution of The Frequency of Immunization Delay

\begin{tabular}{ccc}
\hline Immunization Delay & n & \% \\
\hline Yes & 134 & 48.9 \\
No & 140 & 51.1 \\
Total & 274 & 100.0 \\
\hline
\end{tabular}

The length of time mothers delay immunization varies. Most mothers delay their child's immunization visit for 1-3 months (52\%) and less than one month (27\%). However, some mothers still delay their child's immunization visit for more than six months $(8 \%)$. 


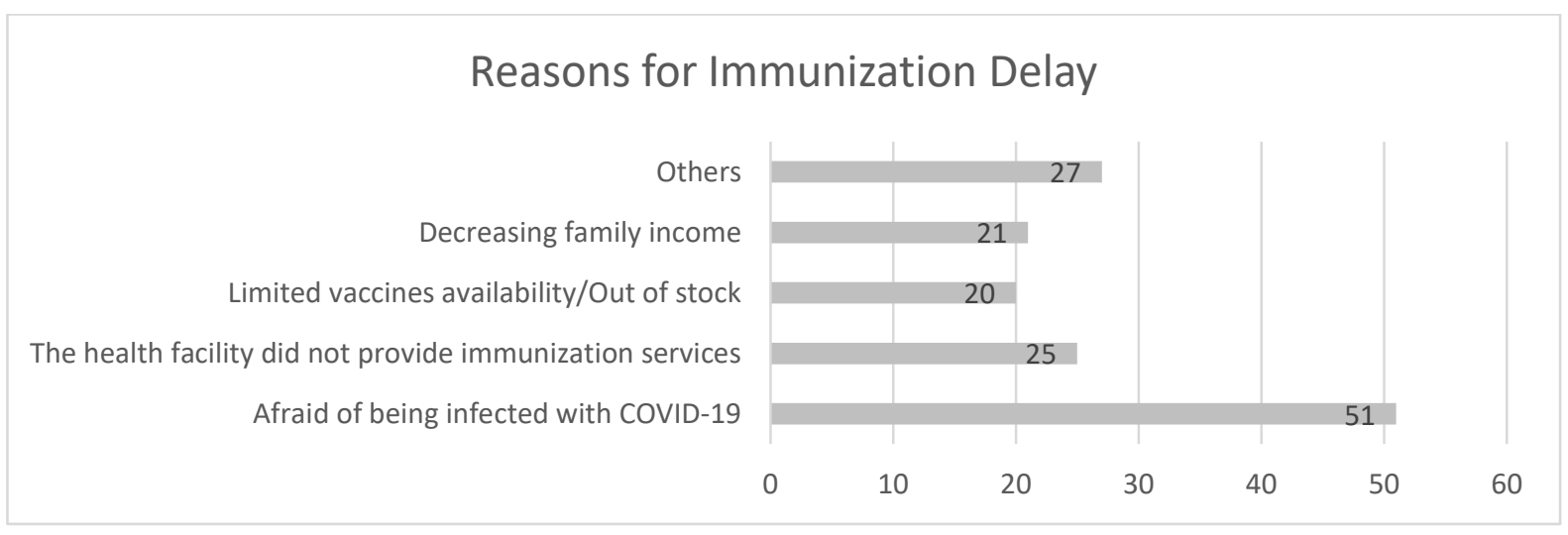

Figure 1. Reasons for Immunization Delay

Mothers who live in West Java province are $48.4 \%$, and the majority are highly educated $(84.7 \%)$. $73 \%$ of mothers who were respondents in this study were housewives. $56.9 \%$ of respondents' family income levels are still less than the regional minimum wage, and the majority have less than three children (75.9\%).

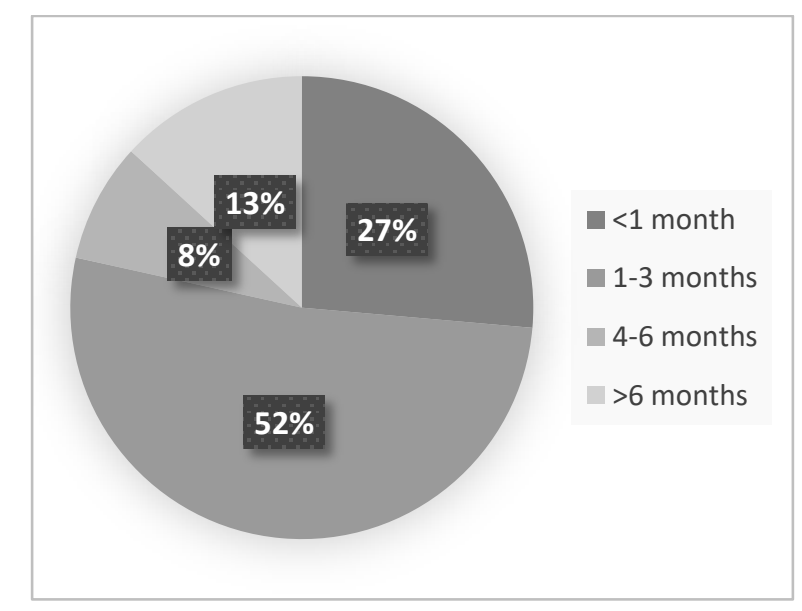

Figure 2. Immunization Delay Duration

Children's age was categorized into less than or equal to nine months and more than nine months. This limit is based on the age of primary MR immunization given to infants nine months before entering the advanced immunization stage. As many as $53.3 \%$ of mothers have children who are more than nine months old. There are $56.9 \%$ of mothers whose children are not participants of the national health insurance. Many mothers do not have private health insurance, and when asked where their child's immunization costs come from, 50.4\% of them answered personal expenses. 
Table 2. Distribution of The Frequency of Respondents' Characteristics

\begin{tabular}{|c|c|c|}
\hline Variable & $\mathbf{n}$ & $\%$ \\
\hline \multicolumn{3}{|l|}{ Province } \\
\hline DKI Jakarta & 82 & 29.8 \\
\hline West Java & 133 & 48.4 \\
\hline Banten & 60 & 21.8 \\
\hline \multicolumn{3}{|l|}{ Education } \\
\hline Low & 42 & 15.3 \\
\hline High & 232 & 84.7 \\
\hline \multicolumn{3}{|l|}{ Occupation } \\
\hline Work & 74 & 27.0 \\
\hline Not Work & 200 & 73.0 \\
\hline \multicolumn{3}{|l|}{ Family Income } \\
\hline$<$ regional minimum wage & 156 & 56.9 \\
\hline$\geq$ regional minimum wage & 118 & 43.1 \\
\hline \multicolumn{3}{|l|}{ Number of Children } \\
\hline$\geq 3$ children & 66 & 24.1 \\
\hline$<3$ children & 208 & 75.9 \\
\hline \multicolumn{3}{|l|}{ Child age } \\
\hline$>9$ months old & 146 & 53.3 \\
\hline$\leq 9$ months old & 128 & 46.7 \\
\hline \multicolumn{3}{|l|}{ BPJS membership } \\
\hline Yes & 156 & 43.1 \\
\hline No & 118 & 56.9 \\
\hline \multicolumn{3}{|l|}{ Private Insurance membership } \\
\hline Yes & 38 & 13.9 \\
\hline No & 236 & 86.1 \\
\hline \multicolumn{3}{|l|}{ Source of immunization fee } \\
\hline Personal & 138 & 50.4 \\
\hline Insurance or office reimbursement & 136 & 49.6 \\
\hline
\end{tabular}

Immunization is an action taken to actively generate/enhance a person's immune system through the provision of vaccines so that they do not fall ill easily (resistant) or only experience mild illness if later exposed to a disease. ${ }^{9}$ Based on the Regulation of the Minister of Health of the Republic of Indonesia number 12 of 2017, routine immunization is divided into two, namely primary immunization and advanced immunization. Basic immunization is immunization given to infants aged $0-12$ months or under one year. ${ }^{10}$ Diseases prevented through primary immunization include Hepatitis B, Poliomyelitis, Tuberculosis, Diphtheria, Pertussis, Tetanus, Pneumonia, and Meningitis caused by Hemophilus influenza type B (Hib) and measles.

Immunization as an essential health service to prevent dangerous diseases in children is deemed necessary to continue even amid a pandemic like today. However, children who are a vulnerable group suffering from PD3I must still be protected from various dangerous diseases through immunization. Based on the technical instructions for immunization services during the Covid-19 pandemic released by the Ministry of Health of the Republic of Indonesia, several principles serve as a reference in implementing immunization amid the Covid-19 pandemic. These principles include: basic and advanced immunizations are still sought to be given in full 
with implementation according to schedule, immunization service operations are still carried out by following local government policies, optimizing PD3I surveillance activities and reporting, maintaining a safe distance (1-2 meters) and implementing PPI principles.

Based on the consideration of risks and benefits, the continuity of immunization services will continue to be carried out by taking into account the following steps: Risk assessment and mapping will continue to be carried out by the Health Service and primary health care based on epidemiological analysis of local Covid-19 transmission, local routine immunization coverage, and the situation of Preventable Diseases With Immunization (PD3I), recommendations for the continuity of the implementation of immunization services in the work area are made by the local health office and health center. To obtain support from regional leaders and their staff, advocacy is carried out by the Health Office and primary health care to local governments regarding policies and operations so that immunization services can run and provide optimal protection for children. The Health Service and primary health care still carry out intensive immunization coverage and PD3I surveillance. Community groups at high risk of outbreaks can be identified early and become priority catch-up immunizations after the pandemic. ${ }^{11}$

\section{CONCLUSION AND SUGGESTIONS}

The study found the proportion of mothers who delayed their children's immunization was $48,9 \%$. The most common reasons are fear of being infected with COVID-19, health facilities not providing immunizations for children, limited vaccine availability, and declining family income during the pandemic. The government should increase the promotion of primary immunization to the community and ensure the availability, safety, and implementation of health protocols in health care facilities.

\section{REFERENCES}

1. Jakarta Smart City. Informasi Dasar COVID-19 [Internet]. 2020 [cited 2020 Jun 9]. Available from: https://corona.jakarta.go.id/id/faq

2. Portal Informasi Indonesia. Kasus Covid-19 Pertama, Masyarakat Jangan Panik [Internet]. [cited 2020 Jun 9]. Available from: https://indonesia.go.id/narasi/indonesiadalam-angka/ekonomi/kasus-covid-19-pertama-masyarakat-jangan-panik

3. Santoli JM, Lindley MC, DeSilva MB, Kharbanda EO, Daley MF, Galloway L, et al. Effects of the COVID-19 Pandemic on Routine Pediatric Vaccine Ordering and Administration - United States, 2020. MMWR Morbidity and Mortality Weekly Report 
[Internet]. 2020 May 15 [cited 2020 Jun 2];69(19):591-3. Available from: http://www.cdc.gov/mmwr/volumes/69/wr/mm6919e2.htm?s_cid=mm6919e2_w

4. Stephenson J. Sharp Drop in Routine Vaccinations for US Children Amid COVID-19 Pandemic. JAMA Health Forum [Internet]. 2020 May 1 [cited 2020 Jun 2];1(5):e200608-e200608. Available from: https://jamanetwork.com/channels/healthforum/fullarticle/2766119

5. Kemenkes: 83,9 Persen Pelayanan Imunisasi Terdampak Pandemi Covid-19 [Internet]. [cited 2020 Jun 9]. Available https://nasional.kompas.com/read/2020/06/08/14150131/kemenkes-839-persenpelayanan-imunisasi-terdampak-pandemi-covid-19

6. Imunisasi di Papua Minim Saat Pandemi - Kompas.id [Internet]. [cited 2020 Jun 2]. Available from: https://kompas.id/baca/nusantara/2020/05/13/imunisasi-di-papuaminim-saat-pandemi-korona/

7. IDAI: Covid-19 Hambat Imunisasi, Orangtua Takut Bawa Anak ke Posyandu [Internet]. [cited 2020 Jun 9]. Available https://nasional.kompas.com/read/2020/06/08/14095291/idai-covid-19-hambatimunisasi-orangtua-takut-bawa-anak-ke-posyandu

8. Stanley Lemeshow, David W Hosmer Jr JK, Lwanga and SK. Adequacy of Sample Size in Health Studies [Internet]. West Sussex: World Health Organization; 1990 [cited 2021 Jun 8]. Available from: http://apps.who.int/iris/bitstream/handle/10665/41607/0471925179_eng.pdf;jsessionid=1 9DC95DBC86242F05002841C4B9D83EF?sequence=1

9. Hadianti DN, Mulyati E, Ratnaningsih E, Sofiati F, Saputro H, Sumastri H, et al. Buku Ajar Imunisasi [Internet]. Jakarta: Pusat Pendidikan dan Pelatihan Tenaga Kesehatan; 2014. 1. Available from: http://bppsdmk.kemkes.go.id/pusdiksdmk/wpcontent/uploads/2017/10/03Buku-Ajar-Imunisasi-06-10-2015-small.pdf

10. Kementerian Kesehatan RI. Peraturan Menteri Kesehatan Republik Indonesia Nomor 12 Tahun 2017 Tentang Penyelenggaraan Imunisasi. Jakarta; 2017.

11. Summary of national immunization technical guidance during COVID-19 pandemic. 
Volume I Tahun 2021

November 2021
E-ISSN: 2808-5361

http://e-journal.fkmumj.ac.id/
Proceeding The First Muhammadiyah InternasionalPublic Health and Medicine Conference 